\title{
Crested wheatgrass growth and replacement following fer- tilization, thinning, and neighbor plant removal
}

\author{
BRET E. OLSON AND JAMES H. RICHARDS
}

\section{Abstract}

The growth and annual replacement of crested wheatgrass (Agropyron desertorum (Fisch. ex Link) Schult.) tillers are affected by resource availability. Fertilization and grazing affect the resources available to erested wheatgrass plants directly, by increasing nutrient supply or by reducing photosynthetic area and root elongation, and indirectly, by changing the competitive status of neighboring plants. To determine the time and manner of crested whent jrass response to alterations in resource avallability, we assessed the growth, flowering, and replacement of tillers on plants treated as follows: tiller thinning, neighbor plant removal, combined thinning and neighbor plant removal, and nitrogen fertilization. These treatments were repeated on different sets of plants in early spring 1984 and 1985. Plant response was inferred from tiller heights, number of flowering culms, and new spring tiller production within the season of manipulation, and the number and heights of replacement tillers the following spring. Neighbor removal, and in 1 year fertilization, increased the size of tillers and stimulated the emergence of new spring tillers. Fertilization effects did not persist into the following year whereas neighbor removal increased annual tiller replacement at least two-fold on target plants. Tiller-tiller competition was not important in plants of crested wheatgrass because tiller growth and replacement on thinned plants did not differ from that of intact plants. This result occurred when thinned and intact plants were compared when both were growing with or without neighbors. Thinned plants replaced only the remaining tillers by the following spring. They did not regain their pretreatment status, presumably because of the encroachment of neighbors. These results indicate that thinned plants probably would lose their position in a plant community unless their neighbors are affected similarly.

Key Words: Agropyron desertorum, bunchgrass, tiller dynamics, competition

The productivity of grasslands fluctuates in time and space as water and nutrient availability varies. Populations of long-lived clonal grasses in these grasslands may respond to fluctuations in water and nutrient availability by altering the number of plants, the number of tillers per plant, or the size of individual tillers. In many undisturbed grasslands, increases in plant numbers by seedling recruitment or reductions by the mortality of established bunchgrasses are uncommon (West et al. 1979, Gurevitch 1986, Salihi and Norton 1987). When plant population dynamics are unimportant in grasslands, the response to water and nutrient availability occurs in the plasticity of tiller numbers per plant, and tiller size.

Harper (1977) cites several studies in which tiller (or shoot) and plant population processes maintain a dynamic equilibrium with

\footnotetext{
Authors are research associate, Reclamation Research Unit, Montana State University, Bozeman 59717; and associate professor, Department of Range Science and the Ecology Center, Utah State University, Logan 84322-5230. At the time of the research, the first author was research assistant, Department of Range Science, Utah State University, Logan.

The Utah Agricultural Experiment Station (Project 780) and the National Science Foundation (BSR-8207171 and BSR-8705492) supported this research. This is Journal Paper No. 3368 of the Utah Agricultural Experiment Station, Logan, Utah. We thank J.L.K. Pedersen for field assistance and D.A. Pyke for constructive comments on the manuscript.

Manuscript accepted 1 September 1988.
}

resource availability, but most of these studies were conducted with rhizomatous grasses in glasshouses or growth chambers. Several field studies have shown that the removal of neighboring bunchgrasses increases tiller number, tiller size, or basal area of the remaining grasses (Mueggler 1972, Robberecht et al. 1983, Fowler 1986, Gurevitch 1986, Nobel and Franco 1986). Competition among grasses is usually used to explain these responses. Within grasses, tiller-tiller interactions may also be competitive (Kirby and Faris 1972, Colvill and Marshall 1984) or mutually beneficial (Gifford and Marshall 1973, Welker et al. 1985). A positive response of grasses to neighbor removal could be explained by a relaxation of tiller-tiller competition. Competition among tillers has seldom been determined with grasses in the field.

In grasslands, resource variability may result from localized disturbances or areas of defecation by large herbivores, or changes in the competitive status of grasses following grazing. Because of the hierarchical organization of bunchgrasses, grass response to resource variability will first be expressed in population processes of tillers.

For this study, we used the tussock-forming Nordan crested wheatgrass (Agropyron desertorum Fisch. ex Link) Schult.). Crested wheatgrass has been established on more than 5 million hectares in western North America because it tolerates drought and herbivory better than most of the native grasses (Rogler and Lorenz 1983). Tiller growth, flowering, and replacement were assessed in the field following: (i) fertilizing small areas, (ii) thinning individual plants, and (iii) removing neighbor plants. These treatments simulated areas of resource enhancement, a reduction in the competitive status of plants, and a reduction in plant densities, respectively.

Plant response to such treatments may be expressed immediately or in following years. Therefore, growth, tillering, and flowering within the spring growing season and tiller replacement by the following spring growing season were monitored. Although the focus of this study was on tiller population processes, plant response can be inferred directly, and population and community dynamics indirectly, from such observations.

\section{Materials and Methods}

The study area, Tintic Valley in west-central Utah $\left(39^{\circ} 51 \mathrm{~N}\right.$, $112^{\circ} 08^{\prime} \mathrm{W}, 1,750$ meters above sea level), typifies Great Basin foothill rangelands. Soils are Typic Haploxerolls; textures range from coarse to fine sandy loams. Utah juniper (Juniperus osteosperma (Torr) Little) and basin big sagebrush (Artemisia tridentata ssp. tridentata Nutt.) were mechanically removed at the site in 1951. That autumn, crested wheatgrass was seeded to increase livestock forage and remains the dominant species. Long-term (25-year) average annual precipitation $9 \mathrm{~km}$ from the site is 370 $\mathrm{mm}$. During this study, weather information was obtained from an automated station located $1 \mathrm{~km}$ from the site. Total annual precipitation was slightly above the long-term average in 1984 (122\%) and 1985 (108\%).

Tillers of crested wheatgrass live a maximum of 14 months at our site. Without perturbation, almost all tillers are produced in 
autumn, overwinter, resume growth in spring, flower in late June, and senesce shortly thereafter. With the onset of autumn rains, replacement tillers are produced from axillary buds on the senescent tillers (Mueller and Richards 1986).

The study was repeated during 2 years on different sets of plants. Treatments were imposed on 20-21 April 1984 and 23-24 April 1985,2 to 3 weeks after snowmelt. The treatments were: plant thinning, neighbor plant removal, combined plant thinning and neighbor plant removal (1985-1986 cycle only), nitrogen fertilization, and controls. Plants were thinned by selectively removing $50 \%$ of the tillers on a plant with a razor blade. Care was taken not to damage adjacent tillers. Neighboring plants within a $1.5 \mathrm{~m}$ radius in 1984, $1 \mathrm{~m}$ radius in 1985, of target individuals were removed with a glyphosate herbicide. We used a nonpersistent herbicide rather than mechanical removal to minimize soil disturbance. Nitrogen fertilizer was applied as ammonium nitrate in solution at $56.1 \mathrm{~kg} \mathrm{ha}^{-1}$ of nitrogen. At the same time all other treatments received an equivalent watering treatment.

We used a randomized complete block design with 3 replicates. Within each block, a 5-m by 5-m plot was randomly assigned to each of 4 treatments in 1984, and to 5 treatments in 1985. A 1-meter buffer separated each plot. In each plot, 5 randomly selected plants were monitored. In the thinning and neighbor removal treatments, only monitored plants were treated whereas all plants within fertilized plots received treatment. We analyzed the mean response of the 5 monitored plants.

To determine plant response, 20 and 10 tillers per plant were marked with wire rings on 9 May 1984 and 11 May 1985, respectively. Half of the marked tillers were equally spaced on the perimeter and the remaining tillers were similarly spaced within the core of the plant. Overall, each treatment consisted of 300 tillers in 1984, 150 in 1985 , evenly distributed on 15 plants ( 5 plants per treatment per block, 3 blocks).

In both years, tillers were measured immediately after all had been marked and subsequent observations were at 7-day intervals until summer senescence. Observations included tiller heights (most extended leaf), emergence of new spring tillers, and the phenological status of all marked and new spring tillers. All tillers are produced intravaginally in this species; therefore, new spring tillers and autumn tillers emerged within the wire rings of their living and senescent progenitors, respectively. Most autumn tillers survived winter. Those that survived were replacements for the marked tillers that had been subjected to treatment a year earlier. Annual tiller replacement was the average number of replacement tillers per progenitor. Observations on the replacement tillers included heights.

All data were analyzed as a randomized complete block analysis of variance and means were separated with Tukey's standardized range test. Each year was analyzed separately. Control plants were not included in the analysis of spring tiller production because they did not produce new spring tillers. Within a treatment, analysis of variance of new spring tiller heights included only plants which produced at least 1 new tiller.

\section{Results}

In cold-desert regions such as the Great Basin, winter precipitation (snow) is the main source of soil water for the spring-early summer growing period. At our site, September through March precipitation was $30 \%$ greater in $1984(293 \mathrm{~mm})$ than in $1985(227$ $\mathrm{mm}$ ). In April, as the fall-produced tillers were resuming growth and floral primordia were forming, precipitation was almost $60 \%$ greater in $1984(42.4 \mathrm{~mm})$ than in $1985(26.7 \mathrm{~mm})$. In 1984, April was relatively wet and May was dry whereas the converse occurred in 1985 (Fig. 1).
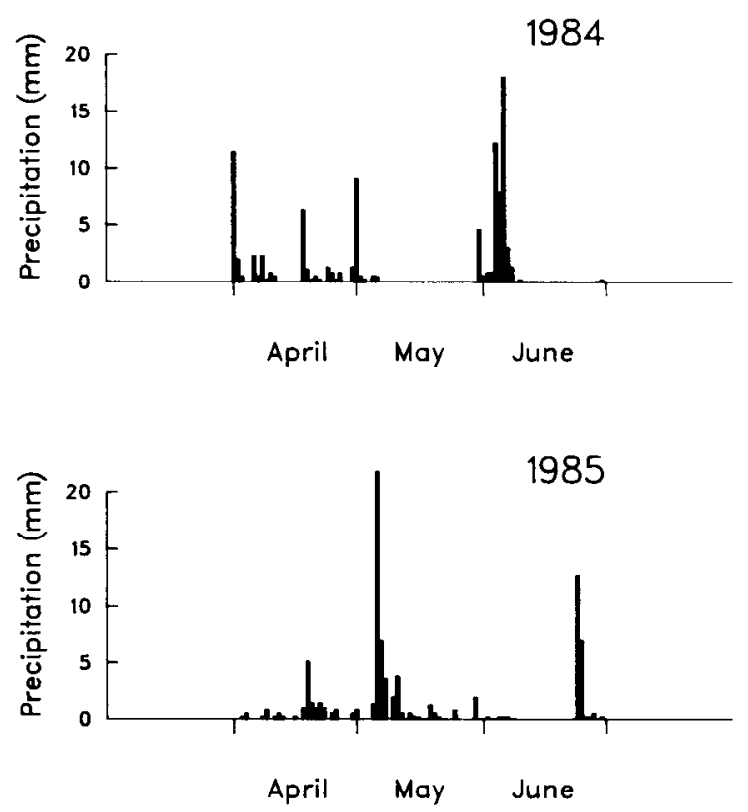

Fig. 1. Spring precipitation during 1984 and 1985 at the Tintic study area.

\section{Tiller Growth, Flowering and Production}

Fertilization increased the percentage of flowering culms $(61 \%)$ over all treatments (average 34\%) in 1984 (Fig. $2 a ; P<0.05$ ). In contrast, there were no significant differences among the low percentage (average 10\%) of tillers flowering in 1985. Tillers on fertil-
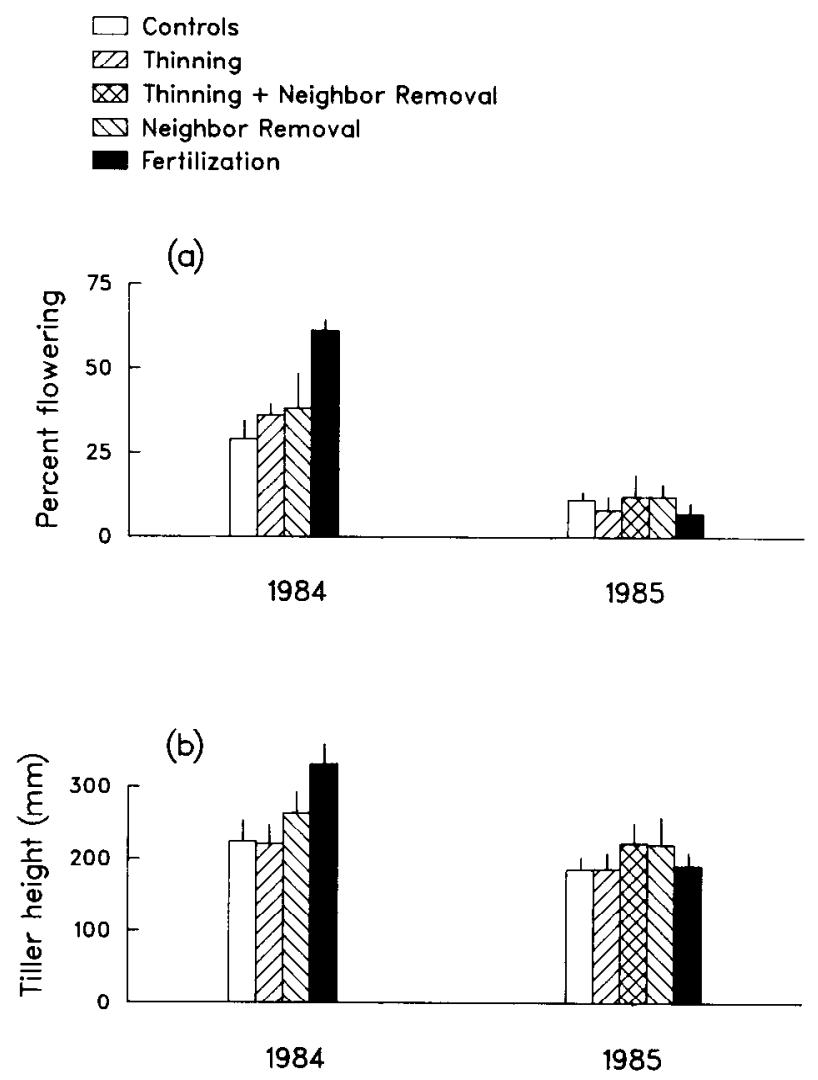

Fig. 2. (a) Percentage of marked tillers of A. desertorum flowering during each growing season. (b) Heights of marked tillers at cessation of growth. Vertical bars represent standard error of the mean $(\mathrm{n}=3)$. 
ized plants were 25 to $50 \%$ taller than all other tillers by late June in 1984 (Fig. 2b; $P<0.05$ ). In 1985, the tillers on plants without neighbors were about $16 \%$ taller than those on plants with neighbors, including the fertilized plants $(P<0.01)$. Average tiller heights in 1985 were lower than in 1984.

All treatments both years stimulated at least some spring tiller production, whereas control plants only produced new tillers in the autumn. There was no significant difference in spring tillering between the fertilized and thinned-neighbor removal plants, and the other treatments in 1985 because of high plant-to-plant variability for tillering (Fig. 3a). Within a treatment, tillering did not

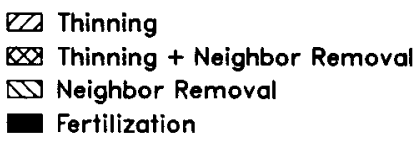

(a)

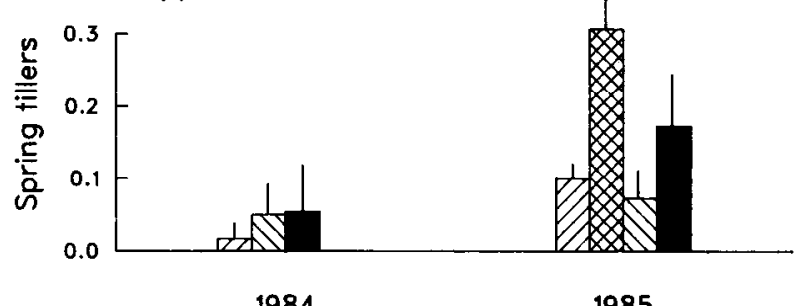

(b)

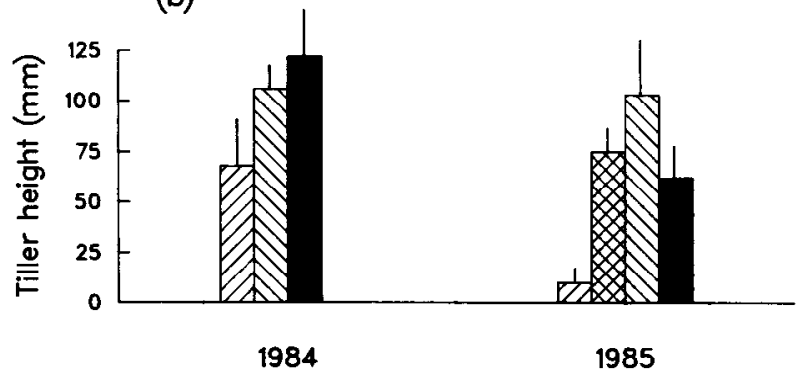

Fig. 3. (a) Average spring tiller production per marked tiller of A. desertorum. (b) Heights of spring-produced tillers at cessation of growth. Vertical bars represent standard error of the mean $(n=3)$.

occur on all plants (range 4-10 of 15 plants in 1984, 1-12 of 15 in 1985). Unlike flowering, which was greater in 1984 than in 1985, spring tillering was higher in 1985 than in 1984. New spring tillers on fertilized plants were taller than those on thinned plants in 1984 (Fig. 3b; $P<0.05$ ); high variability among plants resulted in no significant differences in 1985.

\section{Tiller Replacement by the Following Spring}

Although fertilization and neighbor removal increased tiller growth, flowering, and tillering shortly after the treatments were imposed, effects of fertilization were not evident the following spring (Fig. 4a). However, tiller replacement in both years was much higher on plants whose neighbors had been removed than on those with neighbors, including the fertilized plants (Fig. 4a; $P<0.05$ ). Similarly, replacement tiller height on plants without neighbors was greater than on plants with neighbors both years (Fig. 4b; $P<0.01$ ).

\section{Discussion}

Since establishment and mortality of crested wheatgrass plants

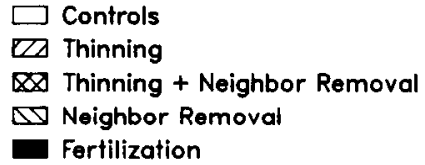

(a)

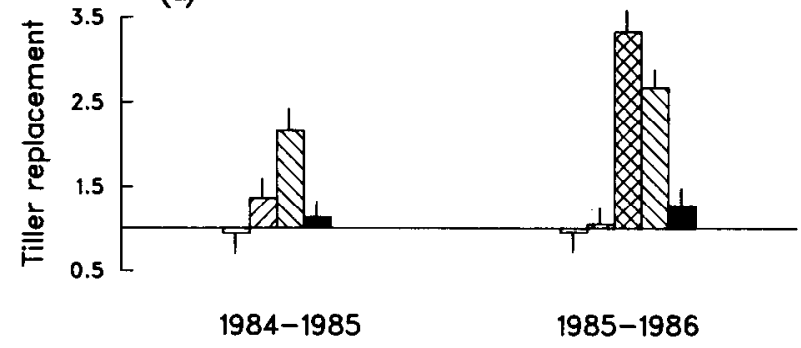

(b)

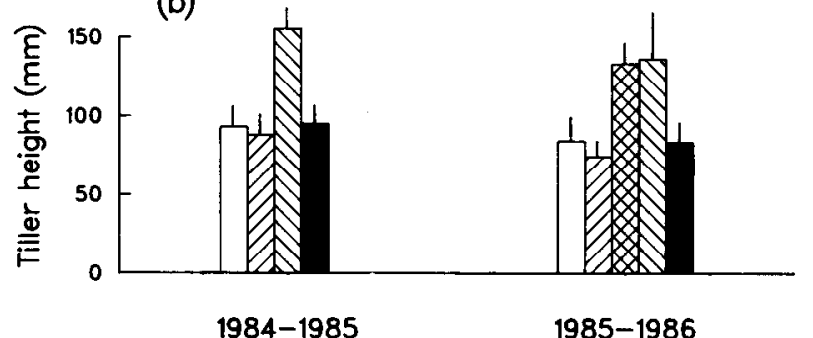

Fig. 4. (a) Annual tiller replacement on plants of A. desertorum 1 year following treatments. (b) Mean height of replacement tillers. The first year indicates the spring when treatments were applied; the second year indicates when replacement was observed. Vertical bars represent standard error of the mean $(\mathrm{n}=3)$.

were infrequent at the study site (Salihi and Norton 1987, M.K. Owens unpublished data), plant response to resource variability was expressed mainly in changes in tiller growth, flowering and replacement. The effects of these processes differed between years and treatments, presumably because each manipulation affected the magnitude of resource availability and the biology of the plants in a different manner.

Roots of crested wheatgrass grow rapidly in the moist upper layers of the soil profile in April and May (Caldwell et al. 1981, Eissenstat 1986). These fine roots effectively increase nitrogen and phosphorus uptake (Caldwell et al. 1981, 1985, 1987), which may enhance floral development and increase tiller growth. Following the wet April of 1984, fertilization did increase flowering and tiller heights (Fig. 2a, b); e.g., tillers on these plants were up to $80 \%$ taller than those on control plants. Others have also found increased tiller size with fertilization of wildland plants (McGraw 1985, Shaver et al. 1986). In contrast, fertilization had no effect on tiller size or flowering following the drier April of 1985, but did increase the production of new spring tillers. Tillering often increases with fertilization (Noble et al. 1979, Fetcher and Shaver 1983, McGraw 1985), usually with a concomitant increase in the mortality of mature tillers. In this study, however, the increase in tillering with fertilization did not increase tiller mortality (unpublished data).

The year to year differences in developmental response to fertilization probably were not influenced by total annual precipitation as both years were slightly above normal, but were affected by the different amounts and timing of spring precipitation (Fig. 1). Small differences in soil moisture during early tiller growth and floral development affect crested wheatgrass response to fertilization (McGinnies 1968). With ample soil moisture in April, increased 
tiller growth and flowering may have been the quickest way for crested wheatgrass to respond to a pulse of nutrients. Such rapid growth did not occur during the dry April of 1985, however. Although nitrogen would have still been available in May, the induction period for floral primordia had passed, thus the nitrogen was apparently allocated to the production of new spring tillers.

Although fertilization increased flowering and tiller size in 1984 and the number of spring tillers in 1985, the effects of fertilization were not evident in 1985 and 1986, respectively. The lack of any carryover effects may reflect the rapid use of the nitrogen, the relatively low rate of application, the continued presence of neighbor plants, immobilization by soil microorganisms (Ingham et al. 1986), or other losses of nitrogen.

McGinnies (1968) found that annual applications of nitrogen fertilizer to crested wheatgrass produced higher yields than biennial applications indicating rapid use, or immobilization, in the year of application. He also detected no carryover effect on yield response to nitrogen applications of less than $67 \mathrm{~kg} \mathrm{ha}^{-1}$, which is higher than the rate that was used in this study. Furthermore, neighbor plants were also fertilized; thus they provided a constant background of competitors for the same resources in time and space.

If our added nitrogen had been immobilized by microorganisms, we would have expected increased production 2 to 3 years after fertilization when the nitrogen is mineralized as some have found in the Great Plains (Mason and Miltimore 1972, White 1985). Increased production was not evident in 1987, 2 to 3 years after the 1984 and 1985 nitrogen applications, however.

Unlike fertilization, neighbor removal eliminated any competitors around monitored plants. Because root systems of neighboring plants overlap substantially in cold desert regions, reduced competition increases resource availability rapidly for the remaining individuals (Caldwell et al. 1985, 1987). Similar rapid increases in resource availability may occur anytime abiotic or biotic factors, e.g., grazing (Olson and Richards $1988 \mathrm{a}$ ), reduce plant size or cause the selective mortality of mature plants on rangelands.

Despite increased resource availability with neighbor removal, flowering and tiller heights increased relatively little following removal (Fig. 2a, b). But neighbor removal, especially when combined with thinning, increased the production of new spring tillers (Fig. 3a). Because flower development and growth of existing tillers were presumably determined soon after neighbors were removed in late April, the production of new spring tillers was probably the only remaining developmental response to enhanced resource availability.

Unlike fertilization, neighbor removal significantly increased tiller replacement by the following spring (Fig. 4a). Annual tiller replacement on plants without neighbors was high enough that the plots could approach pretreatment tiller densities within 2 years (about 500 tillers $\mathrm{m}^{-2}$ ). For example, the neighbor removal treatment in 1985 (radius $=1 \mathrm{~m}$ ) created a $3.14-\mathrm{m}^{2}$ bare zone (aboveground) around target individuals. If target individuals and plants on the perimeter of these bare zones can colonize them equally, then an average-sized plant (100 tillers per plant, unpublished data) in the center could potentially colonize $0.78 \mathrm{~m}^{2}$ of the area. The remaining area would be colonized by plants on the perimeter of the bare zone. A central plant with 390 tillers $\left(500\right.$ tillers $\mathrm{m}^{-2} \times 0.78$ $\mathrm{m}^{2}$ ) would represent full occupation of this area. The 2.6 annual tiller replacement in 1985 would increase tiller numbers from 100 to 260 per plant only 1 year after the removal of neighbors. If this increase in the number of replacement tillers is combined with the $60 \%$ increase in their size relative to controls (Fig. 4b), the forage yield of plants in the center of the $1-\mathrm{m}$ radius (1985) bare zones would exceed that of equal areas nearby. Although the thinnedneighbor removal plants had an even higher replacement than neighbor removal only plants, they began with $50 \%$ fewer tillers thus it would take them longer to reach pretreatment tiller densities.

Tiller processes may reflect either sharing of or competition for resources among tillers within plants (Kirby and Faris 1972, Gifford and Marshall 1973). Plant thinning, by reducing competition or the demands for resource sharing among tillers, should have stimulated growth rates or tillering of the remaining tillers if tillertiller competition was important but it did not. Thinning only reduced the competitive status of plants. Thinned plants maintained themselves with tiller replacement close to or slightly above 1 both years (Fig. 4a), but replacement should have been 2 for these plants to regain pretreatment tiller numbers. Reducing tiller numbers by thinning probably had a concomitant effect on belowground function. Reducing tiller size of crested wheatgrass by severe clipping has been shown to curtail root growth up to $50 \%$ and phosphate acquisition by $60 \%$ within 2 weeks (Richards 1984, Caldwell et al. 1987). In this study, intact neighbors may have quickly occupied soil volume lost by the thinned plants; roots of crested wheatgrass rapidly invade zones of enriched or disturbed soil (Eissenstat 1986, Eissenstat and Caldwell 1988). Such rapid encroachment or resource depletion by neighbors probably prevented thinned plants from regaining their pretreatment status.

To further define the relative importance of tiller-tiller versus plant-plant competition, thinned plants were compared with intact plants in the absence of neighbors. Tiller heights and flowering were similar between thinned and intact plants when both were without neighbors. Thinned plants, however, had somewhat higher spring tillering (Fig. 3a) and tiller replacement (Fig. 4a) than intact plants. These differences likely reflect thinning-induced microclimatic differences within plants that can influence tiller production (Deregibus et al. 1985). Apparently, thinned plants with neighbors could not regain their prethinning size because of plant-plant competition, and not because of constraints on tillering within plants.

The remarkably consistent replacement of tillers on control plants indicated that each of these bunches was maintaining a constant tiller density, and thus competitive position in the stand. Changes in resource availability or competitive status alter this equilibrium, but it can be quickly restored by the high tiller replacement capabilities of crested wheatgrass. Tiller replacement may be constrained, however, by neighboring plants, e.g., thinned bunches with intact neighbors were unable to regain their pretreatment status and their position in the stand. The thinning of bunchgrasses has been observed on many rangelands (Pechanec et al. 1937, Sharp 1970, Olson and Richards 1988b). Our study indicates that the recovery of thinned grasses will depend on the grazed status of their neighbors along with climatic trends. In this colddesert region where plant population dynamics are relatively unimportant, stands of crested wheatgrass apparently persist by rapidly adjusting tiller population processes to changes in resources and neighbors.

\section{Literature Cited}

Caldwell, M.M., J.H. Richards, D.A. Johmson, R.S. Nowak, and R.S. Dzurec. 1981. Coping with herbivory: photosynthetic capacity and resource allocation in 2 semiarid Agropyron bunchgrasses. Oecologia 50:14-24.

Caldwell, M.M. D.M. Ejssenstat, J.H. Richards, and M.F. Allen. 1985 Competition for phosphorus: differential uptake from dual-isotopelabeled interspaces between shrub and grass. Science 228:384-386.

Caldwell, M.M., J.H. Richards, J.H. Manwaring, and D.M. Eissenstat. 1987. Rapid shifts in phosphate acquisition show direct competition between neighboring plants. Nature 327:615-616.

Colvill, K.E., and C. Marshall. 1984. Tiller dynamics and assimilate partitioning in Lolium perenne with particular reference to flowering. Ann. Appl. Biol. 104:543-557. 
Deregibus, V.A., R.A. Sanchez, J.J. Casal, and M.J. Trlica. 1985. Tillering responses to enrichment of red light beneath the canopy in humid natural grassland. J. Appl. Ecol. 22:199-206.

Eissenstat, D.M. 1986. Belowground resource exploitation in semiarid plants: a comparative study using two tussock grasses that differ in competitive ability. Diss., Utah State University, Logan, Utah.

Eissenstat, D.M., and M.M. Caldwell. 1988. Seasonal timing of root growth in favorable microsites. Ecology 69:870-873.

Fetcher, N., and G.R. Shaver. 1983. Life histories of tillers of Eriophorum vaginatum in relation to tundra disturbance. J. Ecol. 71:131-147.

Fowler, N.L. 1986. Density-dependent population regulation in a Texas grassland. Ecology 67:545-554.

Gifford, R.M., and C. Marshall. 1973. Photosynthesis and assimilate distribution in Lolium multiflorum Lam. following differential tiller defoliation. Aust. J. Biol. Sci. 26:517-526.

Gurevitch, J. 1986. Competition and the local distribution of the grass Stipa neomexicana. Ecology 67:46-57.

Harper, J.L. 1977. Population biology of plants. Academic Press, London, U.K.

Ingham, E.R., J.A. Trofymow, R.N. Ames, H.W. Hunt, C.R. Morley, J.C. Moore, and D.C. Coleman. 1986. Trophic interactions and nitrogen cycling in a semi-arid grassland. I. Seasonal dynamics of the natural populations, their interactions and effects on nitrogen cycling. J. Appl. Ecol. 23:597-614.

Kirby, E.J., and D.G. Faris. 1972. The effect of plant density on tiller growth and morphology in barley. J. Agr. Sci. 78:281-288.

Mason, J.L., and J.E. Miltimore. 1972. Ten year yield response of beardless wheatgrass from a single nitrogen application. J. Range Manage. 25:269-272.

MeGinnies, W.J. 1968. Effects of nitrogen fertilizer on an old stand of crested wheatgrass. Agr. J. 60:560-562.

McGraw, J.B. 1985. Experimental ecology of Dryas octopetala ecotypes. III. Environmental factors and plant growth. Arct. and Alp. Res. 17:229-239.

Mueggler, W.F. 1972. Influence of competition on the response of bluebunch wheatgrass to clipping. J. Range Manage. 25:88-92.
Mueller, R.J., and J.H. Richards. 1986. Morphological analysis of tillering in Agropyron desertorum. Ann. Bot. 57:911-921.

Nobel, P.S., and A.C. Franco. 1986. Annual root growth and intraspecific competition for a desert bunchgrass. J. Ecol. 74:1119-1126.

Noble, J.C., A.D. Bell, and J.L. Harper. 1979. The population biology of plants with clonal growth. I. The morphology and structural demography of Carex arenaria. J. Ecol. 67:983-1012.

Olson, B.E., and J.H. Richards. 1988a. Annual replacement of the tillers of Agropyron desertorum following grazing. Oecologia 76:1-6.

Olson, B.E., and J.H. Richards. 1988b. Spatial arrangement of tiller replacement in Agropyron desertorum following grazing. Oecologia 76:7-10.

Pechanec, J.F., G.D. Pickford, and G. Stewart. 1937. Effects of the 1934 drought on native vegetation of the Snake River plains, Idaho. Ecology 18:490-505.

Richards, J.H. 1984. Root growth response to defoliation in two Agropyron bunchgrasses: field observations with an improved root periscope. Decologia 64:21-25.

Robberecht, R., B.E. Mahall, and P.S. Nobel. 1983. Experimental removal of intraspecific competitors-effects on water relations and productivity of a desert bunchgrass, Hilaria rigida. Oecologia 60:21-24.

Rogler, G.A., and R.J. Lorenz. 1983. Crested wheatgrass-Early history in the United States. J. Range Manage. 36:91-93.

Salihi, D.0., and B.E. Norton. 1987. Survival of perennial grass seedlings under intensive management in semiarid rangelands. J. Appl. Ecol. 24:145-153.

Sharp, L.A. 1970. Suggested management programs for grazing crested wheatgrass. Univ. Idaho Forest, Wildl., Range Exp. Sta. Bull. No. 4.

Shaver, G.R., F.S. Chapin, and B.L. Gartner. 1986. Factors limiting seasonal growth and peak biomass accumulation in Eriophorum vaginatum in Alaskan tussock tundra. J. Ecology 74:257-278.

Welker, J.M., E.J. Rykiel, D.D. Briake, and J.D. Goeschl. 1985. Carbon import among vegetative tillers within two bunchgrasses: assessment with carbon-11 labelling. Oecologia 67:209-212.

West, N.E., K.H. Rea, and R.O. Harniss. 1979. Plant demographic studies in sagebrush-grass communities of southeastern Idaho. Ecology 60:376-388.

White, L.M. 1985. Long-term residual effects of nitrogen fertilization on western wheatgrass. J. Range Manage. 38:461-466. 